$\delta$ ELT $\Delta$

Jurnal Ilmiah Pendidikan Matematika

p.ISSN: 2303 -3983 e.ISSN:2548-3994

Vol. 6 No. 2 Juli 2018 Hal $1-10$

\title{
ANALISIS KEMAMPUAN BERPIKIR KRITIS DALAM MENYELESAIKAN MASALAH MATEMATIKA SISWA KELAS VIIIC SMP NEGERI 1 KALIBAWANG
}

\author{
Andi Novantoro \\ (Pendidikan Matematika, FKIP, Universitas PGRI Yogyakarta) \\ Email : andhi.novantoro@gmail.com
}

\begin{abstract}
Abstrak
Penelitian ini bertujuan untuk mengetahui tingkat kemampuan berpikir kritis dalam menyelesaikan masalah matematika siswa kelas VIIIC SMP Negeri 1 Kalibawang Tahun Ajaran 2017/2018. Kemampuan berpikir kritis merupakan kemampuan berpikir tingkat tinggi yang ditandai dengan menganalisis dan membutuhkan informasi tambahan. Aspek kemampuan berpikir kritis meliputi keterampilan dasar, menentukan strategi, memberikan penjelasan sederhana, penjelasan lebih lanjut dan membuat kesimpulan.

Jenis penelitian ini adalah penelitian kualitatif. Subjek dalam penelitian ini adalah siswa kelas VIIIC SMP Negeri 1 Kalibawang yang berjumlah 26 siswa. Teknik pengumpulan data dilakukan dengan uji tes dan wawancara. Pengambilan data menggunakan instrumen berupa soal tes uraian yang berjumlah 4 butir. Hasil pekerjaan siswa diperiksa dan dikelompokkan menjadi 3 kelompok, yaitu kelompok atas, tengah dan bawah. Selanjutnya dilakukan wawancara terhadap 6 siswa secara purposive, yang terdiri dari 2 siswa tiap kelompok. Setiap subjek diwawancarai berdasarkan hasil pekerjaan siswa, selanjutnya data wawancara di tranksripkan dan dilakukan triangulasi untuk menguji keabsahan data.

Hasil penelitian menunjukkan bahwa hasil analisis indikator kemampuan berpikir kritis dalam menyelesaikan soal uraian materi luas dan volume bangun ruang sisi datar balok dan kubus, adalah sebagai berikut : (1) membangun keterampilan dasar (basic support) termasuk dalam kategori tinggi dengan persentase sebesar 75,96\%, (2) menentukan strategi dan taktik (strategy and tactics) untuk menyelesaikan masalah termasuk dalam kategori sedang dengan persentase sebesar 68,03\%, (3) memberikan penjelasan sederhana (elementary clarification) termasuk dalam kategori tinggi dengan persentase sebesar $75,48 \%$, (4) membuat penjelasan lebih lanjut (advances clarification) termasuk dalam kategori sedang dengan persentase sebesar $68,75 \%,(5)$ membuat simpulan (inference) termasuk dalam kategori tinggi dengan persentase sebesar 71,39\%.
\end{abstract}

Kata kunci: Analisis, Kemampuan Berpikir Kritis.

\begin{abstract}
This study aims to determine the level of critical thinking skills in solving mathematics problems students grade VIIIC SMP Negeri 1 Kalibawang Academic Year 2017/2018. Critical thinking was high level thinking, which tag by analyze and need additional explanation. Aspects of critical thinking were basic support, strategy, elementary clarification, advances clarification and make inference.

This type of research is qualitative research. Subjects in this study are students of class VIIIC SMP Negeri 1 Kalibawang, consist of 26 students. Technique of collecting data are done by test and interview test. Taking data using the instrument in the form of a description test that have 4 items. Results of student work are examined and grouped into 3 groups, which are high, middle and low groups. Furthermore, interviews are conducted on 6 students purposively, consisting of 2 students per group. Each subject is interviewed based on the student's work, then the interview data is transcript and triangulation is done to test the validity of the data.

The result of the research indicates that the result of the analysis of the critical thinking ability in solving the problem of the material description and the volume of building the flat side space of beams and cubes are as follows: (1) building basic skills included in the high category with the percentage of 75,96\%, (2) determining strategy and tactics to solve problems including in medium category with percentage equal to $68,03 \%$, (3) giving elementary clarification including in high category with percentage equal to $75,48 \%$, (4) make advances clarification included in medium category with percentage equal to $68,75 \%$, (5) make inference included in high category with percentage equal to $71,39 \%$.
\end{abstract}

Keywords: Analysis, Critical Thinking. 


\section{A. Pendahuluan}

Matematika merupakan pelajaran yang diberikan sejak Sekolah Dasar sampai Perguruan Tinggi. Matematika sangat erat hubungannya dengan kata menghitung, akan tetapi seiring dengan bertambahnya kemampuan berpikir manusia, matematika tidak hanya mencakup ilmu menghitung

saja. Matematika memuat konsep-konsep, kemampuan berpikir, bahkan dalam matematika terdapat sebuah permasalahan yang terkadang sangat dekat dengan kehidupan sehari-hari. Hal tersebut tercantum dalam standar isi untuk satuan pendidikan dasar dan menengah mata pelajaran matematika (Depdiknas, 2006: 139) dimana telah disebutkan bahwa, mata pelajaran matematika perlu diberikan kepada semua peserta didik mulai dari sekolah dasar untuk membekali peserta didik dengan kemampuan berpikir logis, analitis, sistematis, kritis, dan kreatif, serta kemampuan bekerjasama.

Hal ini sesuai dengan Peraturan Menteri Pendidikan dan Kebudayaan (Permendikbud) RI Nomor 20 Tahun 2016 tentang Standar Kompetensi Lulusan Pendidikan Dasar dan Menengah, yang tercantum dalam lampiran menyebutkan bahwa :

Dimensi keterampilan untuk SMP/MTs/SMPLB/Paket B adalah memiliki keterampilan berpikir dan bertindak : (1) kreatif, (2) produktif, (3) kritis, (4) mandiri, dan (5) kolaboratif, serta (6) komunikatif melalui pendekatan ilmiah sesuai dengan yang dipelajari di satuan pendidikan dan sumber lain secara mandiri.

Berdasarkan hasil Penilaian Tengah Semester (PTS) siswa kelas VIIIC SMP Negeri 1 Kalibawang menunjukkan bahwa dari 26 siswa hanya 42,31\% yang memperoleh nilai di atas KKM. Banyak siswa yang mendapat nilai kurang pada tipe soal uraian. Dari siswa yang mendapat nilai di atas KKM-pun hanya 3 siswa yang dapat menjawab soal uraian dengan tepat dan lengkap.

Berdasarkan hasil observasi, timbul permasalahan lain ketika melihat pekerjaan siswa dalam menyelesaikan masalah matematika. Saat mengerjakan soal dengan tipe soal uraian, atau soal yang membutuhkan penyelesaian dengan banyak penjelasan dalam hal ini disebut sebagai masalah matematika, kebanyakan siswa masih menjawab dengan asal. Asal di sini dijelaskan yaitu siswa lebih suka menjawab soal dengan langsung ke jawaban, tanpa menuliskan apa yang diketahui dan apa yang ditanyakan. Bahkan tak sedikit yang langsung menjawab tanpa menyertakan rumus solusi dari permasalahan yang disajikan. 
Analisis merupakan salah satu kegiatan untuk dapat mengetahui atau mengukur sejauh mana kemampuan yang dimiliki oleh siswa. Berdasarkan pemaparan di atas, siswa SMP Negeri 1 Kalibawang memiliki kemampuan berpikir kritis yang berbeda-beda. Oleh sebab itu, analisis kemampuan berpikir kritis sangat diperlukan, untuk mengetahui sejauh mana kemampuan berpikir kritis siswa SMP Negeri 1 Kalibawang. Sehingga penulis tertari untuk melakukan penelitian dengan judul "Analisis Kemampuan Berpikir Kritis Dalam Menyelesaikan Masalah Matematika Siswa Kelas VIIIC SMP Negeri 1 Kalibawang”.

\section{B. Metode Penelitian}

Penelitian ini merupakan penelitian kualitatif dengan teknik pengumpulan data yang dilakukan melalui tes dan wawancara. Penelitian ini dilakukan di SMP Negeri 1 Kalibawang yang beralamat di Pantog Wetan, Banjaroya, Kalibawang, Kulon progo. Dimana peneliti mengambil kelas VIIIC sebagai subjek penelitian dengan jumlah 26 siswa. Kemudian akan dilakukan wawancara terhadap 6 siswa yang diambil dari tiga kategori, yaitu kategori kelas atas, kelas tengah dan kelas bawah, masing-masing terdiri dari 2 siswa.

Teknik pengumpulan data ini dilakukan dalam 3 tahap, yaitu tahap awal, tahap pelaksanaan, dan tahap akhir. Tahap awal, dilakukan kegiatan antara lain membuat rancangan penelitian, menentukan siswa dengan pertimbangan karakteristik siswa yang berbeda , menyusun instrumen penelitian, mempersiapkan instrumen penelitian, menentukan waktu dan tempat penelitian. Instrumen penelitian berupa soal tes materi luas dan volume bangun ruang sisi datar balok dan kubus dan pedoman wawancara.

Tahap pelaksanaan, dilakukan kegiatan, di antaranya : melakukan kegiatan pengambilan data, yaitu dengan melakukan tes uji soal kemampuan berpikir kritis terhadap siswa, dalam hal ini adalah siswa SMP kelas VIIIC SMP Negeri 1 Kalibawang. Sebelum dilakukukan tes, tentu saja soal telah divalidasikan kepada salah satu dosen Pendidikan Matemtika Universitas PGRI Yogyakarta. Kemudian data hasil pekerjaan siswa yang diperoleh di koreksi untuk kemudian dirangking dan dikelompokkan menjadi tiga kelas/kategori. Selanjutnya diambil 2 siswa tiap kelas untuk dilakukan wawancara mendalam.

Tahap akhir dilakukan dengan kegiatan : menganalisis hasil tes dengan cara peneliti mendiskripsikan hasil tes setiap siswa berdasarkan indikator, indikator dalam penelitian ini menggunakan indikator kemampuan berpikir kritis menurut Ennis (Lestari, 2015: 90), adalah sebagai berikut : (1) Membangun keterampilan dasar (basic support), (2) Menentukan strategi dan taktik (strategi and tactics) untuk menyelesaikan masalah, (3) Memberikan penjelasan sederhana (elementary clarification), (4) Membuat penjelasan lebih lanjut (advances clarification) dan (5) Membuat simpulan (inference). 
Setelah hasil tes dianalisis, dilanjutkan mentranskripkan hasil wawancara, yang kemudian dijadikan untuk memperkuat data dengan cara triangulasi. Triangulasi adalah teknik pemeriksaan keabsahan data yang memanfaatkan sesuatu yang lain di luar data itu untuk keperluan pengecekan atau sebagai pembanding terhadap data itu (Moleong, 2011: 330). Selanjutnya, peneliti menarik kesimpulan, bagaimanakah tingkat kemampuan berpikir kritis siswa kelas VIIIC Negeri 1 Kalibawang.

Adapun rumus yang digunakan dalam mengetahui tingkat kemampuan berpikir kritis siswa adalah sebagai berikut :

$$
P_{i}=\frac{n x_{t}}{n x_{i}} \times 100 \%
$$

Keterangan :

$P_{i} \quad:$ persentase kemampuan berpikir kritis tiap indikator

$n x_{t}:$ jumlah skor siswa tiap indikator

$n x_{i}:$ jumlah skor ideal tiap indikator

Berikut disajikan juga tabel kategori kemampuan berpikir kritis menurut (Karim,Normaya 2015: 96) yang telah dimodifikasi.

Tabel 1. Tabel Kategori Kemampuan Berfikir Kritis

\begin{tabular}{cc}
\hline Persentase & Kategori \\
\hline $81<x \leq 100$ & Sangat Tinggi \\
$71<x \leq 81$ & Tinggi \\
$62<x \leq 71$ & Sedang \\
$43<x \leq 62$ & Rendah \\
$0<x \leq 43$ & Sangat Rendah \\
\hline
\end{tabular}

\section{Hasil dan Pembahasan}

Untuk dapat mengetahui kemampuan berpikir kritis dalam menyelesaikan masalah matematika siswa kelas VIIIC SMP Negeri 1 Kalibawang. Peneliti melakukan tes tertulis dan wawancara. Tes dilakukan pada hari Jumat, 20 April 2018 sedangkan wawancara dilakukan pada hari Jumat, 27 April 2018.

Berdasarkan hasil analisis, menunjukkan kemampuan berpikir kritis siswa kelas VIIIC SMP Negeri 1 Kalibawang dalam menyelesaikan masalah matematika yang ditinjau dari indikatornya adalah sebagai berikut. Indikator yang pertama adalah Membangun keterampilan dasar (basic support). Pada indikator ini, kemampuan berpikir kritis siswa termasuk dalam kategori tinggi dengan persentase sebesar $75,96 \%$. Hal ini berarti, belum seluruh siswa yang mampu membangun keterampilan dasar namun masih terdapat kekurangan yang dalam hal ini 
adalah menuliskan fakta atau informasi yang ada dalam soal. Sebagai contoh disajikan potongan hasil pekerjaan siswa sebagai berikut.

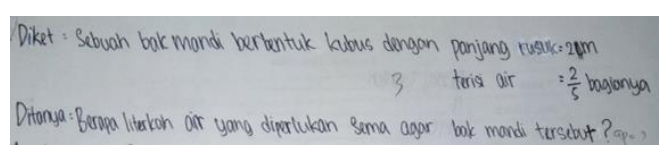

Dari gambar tersebut terlihat bahwa siswa mampu menuliskan fakta atau informasi yang ada pada soal namun masih kurang lengkap. Kekurangan tersebut terletak pada fakta apa yang ditanyakan, subjek hanya menyebutkan "berapa literkah air yang diperlukan Sema agar bak mandi tersebut?". Terkait dengan hal tersebut, disajikan kutipan hasil wawancara antara peneliti dengan subjek. Berikut adalah kutipan wawancara terkait indikator membangun keterampilan dasar.

\begin{tabular}{|lll|}
\hline $\mathrm{P}$ & $:$ Dari soal tersebut apa yang ditanyakan? \\
$\mathrm{S}$ & $:$ & Berapa liter air yang diperlukan Sema? \\
$\mathrm{P}$ & $:$ & Coba kamu lihat hasil pekerjaan kamu. Kamu bacakan yang ditanyakan! \\
$\mathrm{S}$ & $:$ & Berapa liter air yang diperlukan Sema agar bak mandi tersebut? \\
$\mathrm{P}$ & $:$ & Agar bak mandi tersebut bagaimana? \\
$\mathrm{S}$ & $:$ & Terisi pemuh Pak. \\
$\mathrm{P}$ & : & Ok, kenapa kamu menuliskannya seperti itu? \\
$\mathrm{S}$ & $:$ Kurang teliti Pak, lupa menuliskan. \\
\hline
\end{tabular}

Kutipan wawancara tersebut menunjukkan bahwa subjek mampu menyebutkan fakta atau informasi beserta apa yang ditanyakan dengan sedikit kekurangan. Hal ini terjadi karena kekurang telitian subjek ketika mengerjakan soal.

Berdasarkan triangulasi dari hasil tes subjek dan hasil wawancara peneliti dengan subjek, dapat dikatakan bahwa data subjek terkait indikator membangun keterampilan dasar adalah valid. Jadi, dapat ditarik kesimpulan bahwa subjek belum mampu membangun keterampilan dasar dengan tepat. Subjek dalam menentukan fakta atau informasi terkait soal masih terdapat sedikit kekurangan.

Indikator ke dua adalah menentukan strategi dan taktik (strategy and tactics) untuk menyelesaikan masalah. Pada indikator ini, kemampuan berpikir kritis siswa termasuk dalam kategori sedang dengan persentase sebesar $68,03 \%$. Hal ini berarti, belum seluruh siswa yang mampu membangun keterampilan dasar namun masih terdapat kekurangan atau kesalahan yang dalam hal ini adalah menentukan rumus untuk menyelesaikan sebuah permasalahan. Sebagai contoh disajikan potongan hasil pekerjaan siswa sebagai berikut.

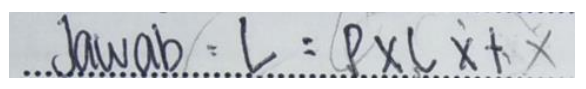

Dari gambar tersebut terlihat bahwa siswa belum mampu menuliskan rumus atau menentukan strategi dalam menyelesaikan soal dengan tepat, dalam hal ini subjek telah menentukan rumus subjek namun masih salah. Kesalahan yang dilakukan subjek adalah 
menuliskan rumus luas permukaan balok adalah $p \times l \times t$, sedangkan rumus permukaan balok yang benar adalah $2(p \times l)+2(p \times t)+2(l \times t)$. Terkait dengan hal tersebut, disajikan kutipan hasil wawancara antara peneliti dengan Subjek. Berikut adalah kutipan wawancara terkait indikator menentukan strategi dan taktik (strategy and tactics) untuk menyelesaikan masalah.

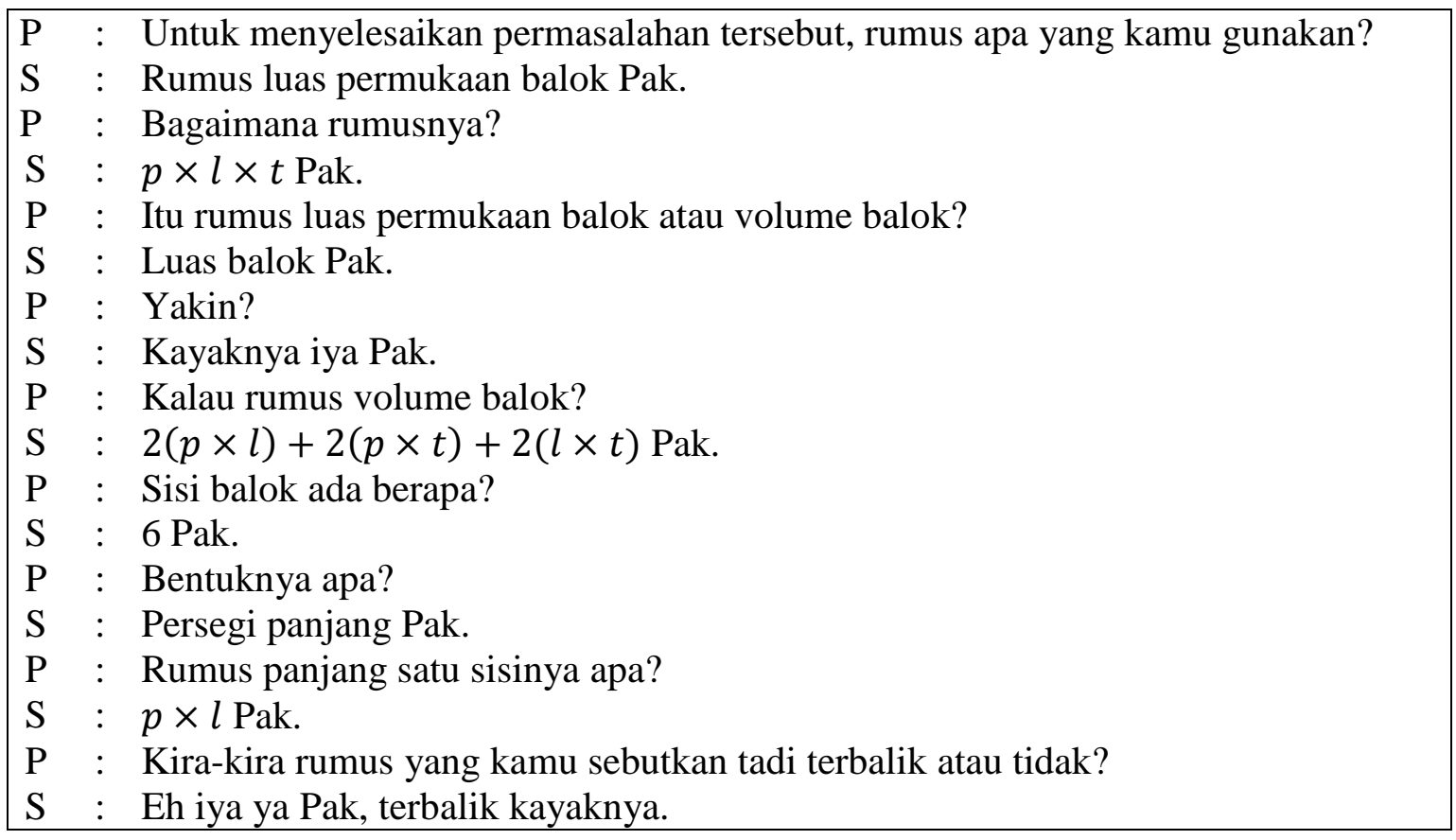

Kutipan wawancara tersebut menunjukkan bahwa subjek mampu menentukan rumus untuk menyelesaikan masalah namun masih salah. Hal ini dikarenakan subjek belum paham dengan strategi atau rumus untuk menyelesaikan masalah atau soal tersebut.

Berdasarkan triangulasi dari hasil tes subjek dan hasil wawancara peneliti dengan subjek, dapat dikatakan bahwa data subjek terkait indikator menentukan strategi dan taktik (strategy and tactics) untuk menyelesaikan masalah adalah valid. Jadi, dapat ditarik kesimpulan bahwa subjek belum mampu menentukan strategi dan taktik (strategy and tactics) untuk menyelesaikan masalah dengan tepat, dengan kata lain subjek masih salah dalam menentukan rumus untuk menyelesaikan masalah atau soal.

Indikator ke tiga adalah memberikan penjelasan sederhana (elementary clarification). Pada indikator ini, kemampuan berpikir kritis siswa termasuk dalam kategori tinggi dengan persentase sebesar $75,48 \%$. Hal ini berarti, belum seluruh siswa yang mampu memberikan penjelasan sederhana (elementary clarification) secara tepat, yang berarti siswa mampu memberikan penjelasan sederhana namun masih terdapat kekurangan-kekurangan. Sebagai contoh disajikan potongan hasil pekerjaan siswa sebagai berikut. 
$=2(25 \cdot 8)+2(25.3)+2(8.3)$

$=400+150+48+3$

$=590 \cdot \mathrm{cm}$

Dari gambar tersebut terlihat bahwa subjek mampu memberikan penjelasan sederhana dalam menyelesaikan soal, namun masih terdapat sedikit kekurangan. Kekurangan tersebut terdapat pada penentuan satuan. Subjek menuliskan satuan luas permukaan balok adalah $\mathrm{cm}$, sedangkan satuan yang tepat adalah $\mathrm{cm}^{2}$. Terkait dengan hal tersebut, disajikan kutipan hasil wawancara antara peneliti dengan Subjek. Berikut adalah kutipan wawancara terkait indikator memberikan penjelasan sederhana (elementary clarification).

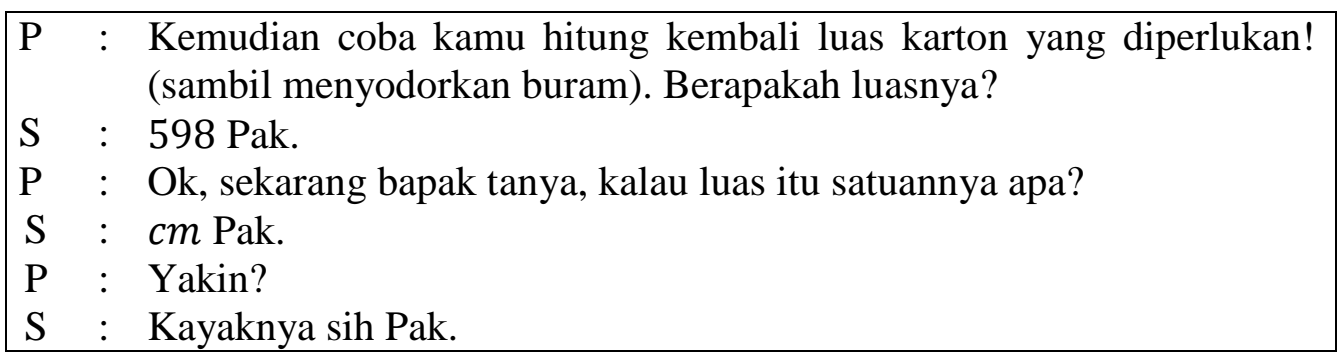

Kutipan wawancara tersebut menunjukkan bahwa subjek mampu memberikan penjelasan sederhana dalam menyelesaikan soal, namun masih terdapat sedikit kekurangan. Kekurangan tersebut terletak dalam penentuan satuan luas permukaan balok. Subjek salah dalam dalam menentukan satuan luas permukaan balok. Hal tersebut dikarenakan kurang pahamnya subjek terkait satuan luas dan volume. Hal ini juga terlihat dari keraguan siswa ketika menjawab pertanyaan dalam wawancara.

Berdasarkan triangulasi dari hasil tes subjek dan hasil wawancara peneliti dengan subjek, dapat dikatakan bahwa data subjek terkait indikator memberikan penjelasan sederhana (elementary clarification) adalah valid. Jadi, dapat ditarik kesimpulan bahwa subjek belum mampu memberikan penjelasan sederhana (elementary clarification) dengan tepat, dalam hal ini subjek masih salah dalam menentukan satuan luas permukaan balok.

Indikator ke empat adalah membuat penjelasan lebih lanjut (advances clarification). Pada indikator ini, kemampuan berpikir kritis siswa termasuk dalam kategori sedang dengan persentase sebesar $68,75 \%$. Hal ini berarti, belum seluruh siswa yang mampu membuat penjelasan lebih lanjut (advances clarification) secara tepat, atau dengan kata lain siswa mampu membbuat penjelasan lebih lanjut namun masih terdapat kekurangan-kekurangan dan bahkan masih salah. Sebagai contoh disajikan potongan hasil pekerjaan siswa sebagai berikut. 


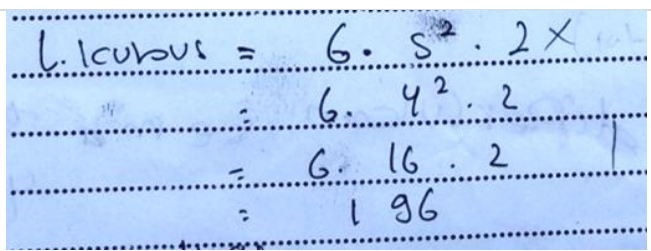

Dari gambar tersebut terlihat bahwa subjek mampu membuat penjelasan lebih lanjut namun masih salah. Berdasarkan gambar tersebut dapat diketahui dalam menentukan luas kubus dengan sisi yang diperpanjang menjadi 2 kali panjang semula masih salah. Subjek menuliskan bahwa untuk menentukan luas kubus yang baru yaitu luas kubus yang lama dikalikan dua. Terkait dengan hal tersebut, disajikan kutipan hasil wawancara antara peneliti dengan Subjek. Berikut adalah kutipan wawancara terkait indikator membuat penjelasan lebih lanjut (advances clarification).

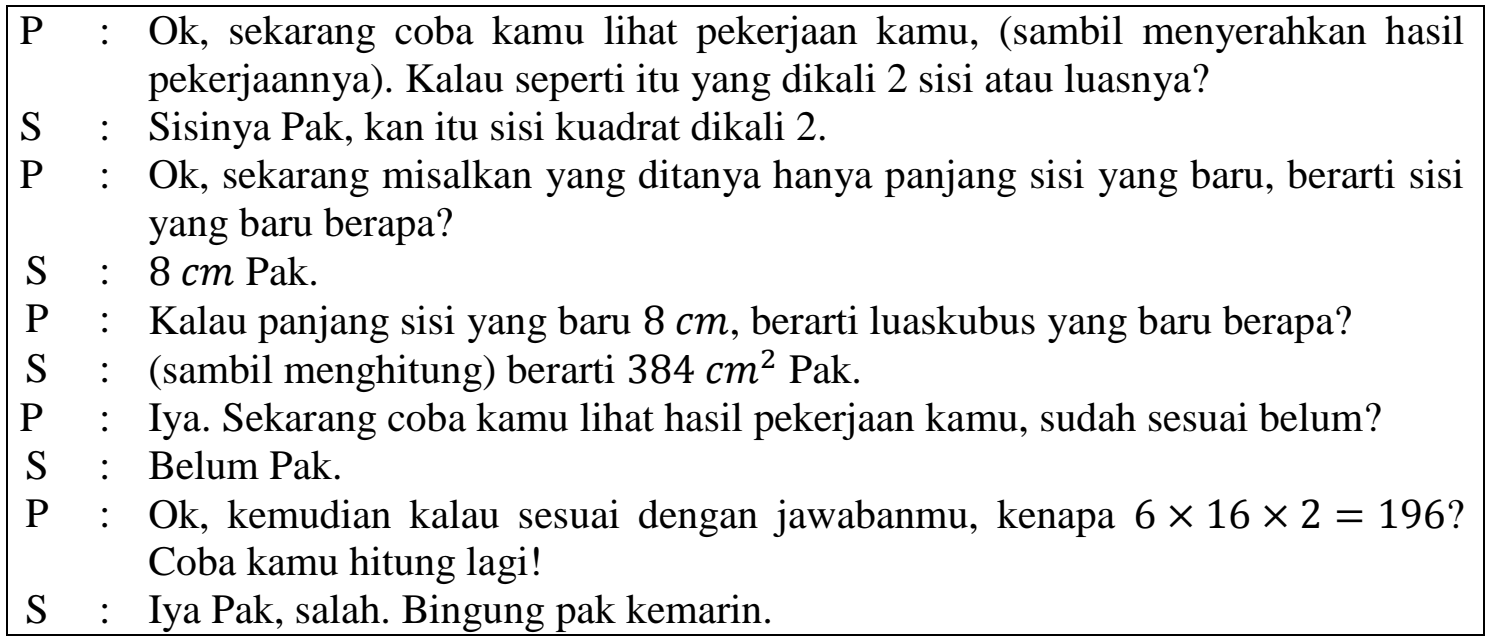

Kutipan wawancara tersebut menunjukkan bahwa subjek mampu membuat penjelasan lebih lanjut dalam menyelesaikan soal, namun masih salah. Kesalahan tersebut dikarenakan kurng pahamnya subjek untuk menyelesaikan masalah tersebut.

Berdasarkan triangulasi dari hasil tes subjek dan hasil wawancara peneliti dengan subjek, dapat dikatakan bahwa data subjek terkait indikator membuat penjelasan lebih lanjut (advances clarification) adalah valid. Jadi, dapat ditarik kesimpulan bahwa subjek belum mampu membuat penjelasan lebih lanjut (advances clarification) dengan tepat, dalam hal ini subjek masih salah dalam menentukan luas permukaan kubus yang baru.

Indikator ke lima adalah membuat simpulan (inference). Pada indikator ini, kemampuan berpikir kritis siswa termasuk dalam kategori tinggi dengan persentase sebesar 71,39\%. Hal ini berarti, belum seluruh siswa yang dapat membuat simpulan (inference) dengan tepat, atau dengan kata lain siswa mampu membuat simpulan namun masih terdapat kekurangan-kekurangan, bahkan masih terdapat siswa yang tidak membuat simpulan. Sebagai contoh berikut adalah contoh gambar hasil pekerjaan siswa. 


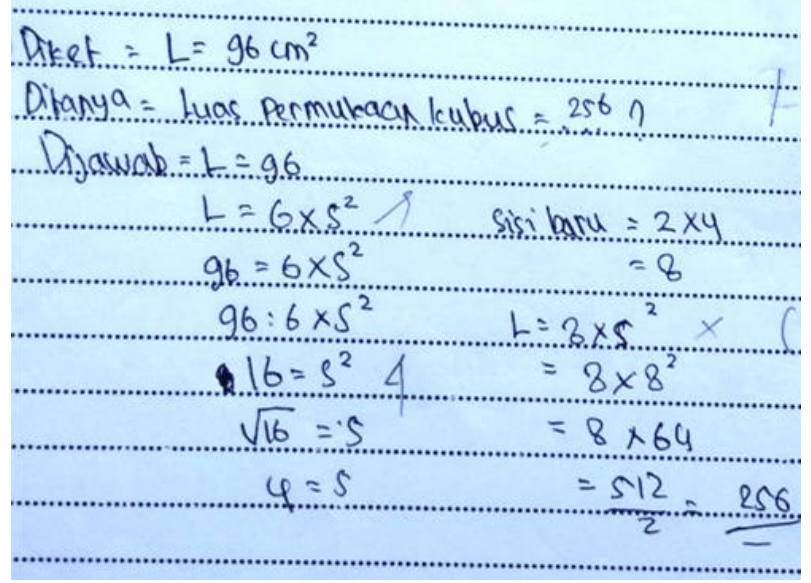

Berikut adalah kutipan wawancara terkait indikator membuat kesimpulan.

\begin{tabular}{|lll|}
\hline $\mathrm{P}$ & $:$ & Sekarang, kamu menuliskan kesimpulannya atau tidak? \\
$\mathrm{S}$ & $:$ Tidak Pak \\
$\mathrm{P}$ & : Kenapa? \\
$\mathrm{S}$ & : & Soalnya saya kira saya sudah menuliskan di yang titik-titik tadi Pak. \\
\hline
\end{tabular}

Kutipan wawancara tersebut menunjukkan bahwa subjek TFR tidak mampu membuat kesimpulan pada soal nomor 2. Hal tersebut dikarenakan, subjek TFR beranggapan bahwa hasil akhirnya telah dituliskan pada indiator membangun keterampilan dasar. Subjek TFR telah menuliskan "luas permukaan kubus $=256$ ?", dan subjek berpikir itu sama dengan kesimpulan.

Berdasarkan triangulasi dari hasil tes subjek dan hasil wawancara peneliti dengan subjek, dapat dikatakan bahwa data subjek terkait indikator membuat simpulan (inferance) adalah valid. Jadi, dapat ditarik kesimpulan bahwa subjek belum mampu membuat simpulan (inferance).

Berdasarkan hasil penelitian ini dapat disimpulkan bahwa, kemampuan berpikir kritis siswa kelas VIIIC SMP Negeri 1 Kalibawang menurut indikator kemampuan berpikir kritis menurut Ennis (Lestari, 2015: 90) adalah sebagai berikut. (1) Indikator membangun keterampilan dasar berada dalam kategori tinggi dengan persentase 75,96\%; (2) Indikator menentukan strategi dan taktik untuk menyelesaikan masalah berada dalam kategori sedang dengan persentase sebesar 68,03\%; (3) Indikator memberikan penjelasan sederhana berada dalam kategori tinggi dengan persentase sebesar 75,48\%; (4) Indikator membuat penjelasan lebih lanjut berada dalam kategori sedang dengan persentase sebesar 68,75\%; dan (5) indikator membuat simpulan berada dalam kategori tinggi dengn persentase sebesar 71,39\%. 


\section{Daftar Pustaka}

Depdiknas. 2006. Standar Isi Mata Pelajaran Matematika Tingkat Sekolah Dasar dan Menengah. Jakarta: Depdiknas.

Hariyanti.2010.Upaya Meningkatkan Kemampuan Penalaran Matematika Siswa Kelas VIIC SMP Negeri 2 Depok Sleman Dalam Pembelajaran Matematika Melalui Pendekatan Investigasi. Universitas Negeri Yogyakarta.

Karunia, Eka Lestari dan Mokhammad Ridwan Yudhanegara. 2015. Penelitian Pendidikan Matematika. Bandung: PT Refika Aditama.

Permendikbud. 2016. Peraturan Menteri Pendidikan dan Kebudayaan (Permendikbud) RI Nomor 20 Tahun 2016 tentang Standar Kompetensi Lulusan Pendidikan Dasar dan Menengah. Jakarta : Kemendikbud.

Sri Hastuti Noer.2009.Kemampuan Berpikir Kreatif Matematis.Apa, Mengapa, dan Bagaimana.Universitas Negeri Yogyakarta. 